\title{
KONTRIBUSI ZAKAT SEBAGAI SOLUSI MENGHADAPI KRISIS EKONOMI DAN KEUANGAN SOSIAL ISLAM DI MASA PANDEMI COVID-19
}

\author{
Hanik Fitriani \\ Institut Agama Islam Negeri Ponorogo, Indonesia \\ hanikfitriani9@gmail.com
}

\begin{abstract}
Abstrak:
Pada saat ini Indonesia mengalami sebuah kondisi yang tidak teratur karena adana virus covid-19. Sebagaiana kita ketahui bahwa dampak dari virus covid-19 melemahkan Indonesia di berbagai sector terutama ekonomi. Kementerian tenaga kerja menyebut sampai dengan Februari 2021 ada 29,12 juta penduduk Indonesia usia kerja terdampak covid-19 dengan kehilangan pekerjaannya. Besarnya angka PHK akan berdampak pada menurunnya ekonomi keluarga. Islam mengajarkan manusia untuk peduli terhadap sesama dengan kepedulian social yang diajarkan melalui filantropi berupa zakat. Dimensi zakat yang meliputi ketaatan dan kepedulian social diharapkan mampu memberikan solusi atas krisis ekonomi dan keuangan social yang terjadi di masyarakat. Metode penelitian yang dipakai dalam penelitian ini adalah deskriptif kualitatif dengan menggunakan teknik content analisis (analisis isi) dan riset kepustakaan (library research). Metode penelitian yang digunakan untuk mengetahui simpulan dari sebuah teks biasa disebut dengan teknik content analysis.

Dari penelitian ini diperoleh hasil bahwa zakat memiliki dimensi ketaatan dan kepedulian social. Di antara bentuk ketaatan adalah adanya perintah untuk melakukan pembayaran zakat dan sebagai wujud dari kepedulian social adalah zakat didistribusikan kepada mustahik. Terlebih dimasa pandemic seperti ini, banyak orang yang membutuhkan bantuan karena terhimpit keadaan di ambang kemiskinan. Adapun kontribusi yang diberikan zakat untuk menjadi solusi krisis dimasa pandemic adalah pertama, merealisasikan zakat untuk didistribusi sebagai bentuk bantuan langsung dan manfaatnya bisa dirasakan secara langsung, kedua, zakat dapat digunakan sebagai bantuan modal usaha dalam bentuk Qardul Hasan tanpa adanya tambahan margin. ketiga, dana yang terkumpul di BAZ/LAZ/organisasi pengumpul zakat dapat digunakan untuk memperkuat UMKM. Keempat, zakat dapat ditingkatkan dengan penggunaan fintech syariah
\end{abstract}

\section{Keywords: Zakat, Krisis Ekonomi, Keuangan Sosial Islam}

\begin{abstract}
:
At this time, Indonesia is experiencing an irregular condition due to the covid-19 virus. As we know that the impact of the Covid-19 virus weakens Indonesia in various sectors, especially the economy. The Ministry of Manpower said that until February 2021 there were 29.12 million working-age Indonesians affected by Covid-19 by losing their jobs. The large number of layoffs will have an impact on the decline in the family economy. Islam teaches humans to care for others with social care which is taught through philanthropy in the form of zakat. The dimensions of zakat, which include social obedience and concern, are expected to provide solutions to the economic and social financial crises that occur in society. The research method used in this research is descriptive qualitative using content
\end{abstract}


analysis techniques (content analysis) and library research (library research). The research method used to find out the conclusions of a text is called the content analysis technique.

From this research, it is found that zakat has the dimensions of obedience and social care. Among the forms of obedience are orders to make zakat payments and as a form of social concern, zakat is distributed to mustahik. Especially during a pandemic like this, many people need help because they are choked by conditions on the brink of poverty. The contribution given by zakat to become a solution to the crisis during a pandemic is first, realizing zakat to be distributed as a form of direct assistance and the benefits can be felt directly, secondly, zakat can be used as business capital assistance in the form of Qardul Hasan without any additional margins. third, the funds collected at BAZ / LAZ / zakat collection organizations can be used to strengthen MSMEs. Fourth, zakat can be increased by using sharia fintech

Keyword: Zakat, Economic Crisis, Islamic Social Finance

\section{PENDAHULUAN}

Pada saat ini Indonesia mengalami sebuah kondisi yang tidak teratur karena adana virus covid-19. Sebagaiana kita ketahui bahwa dampak dari virus covid-19 melemahkan Indonesia di berbagai sector baik dari segi ekonomi, pendidikan, kesehatan, keagamaan, social dan budaya. Sudah satu tahun virus ini beredar dan memberikan dampak yang luar biasa padasemua aspek terutama pada sektor ekonomi. Adapun dampak besar yang terlihat pada sector perekonomian di antaranya adalah konsumsi rumah tangga yang menurun, ketidakpastian dalam jangka waktu yang lama sehingga diikuti oleh angka investasi yang melemah dan berdampak pada berhentinya UMKM, dan terakhir ekonomi dunia melemah sehingga mengakibatkan turunnya komoditas ekspor dan harga komoditas. ${ }^{1}$

Menurut Bank Dunia, dampak ekonomi dari covid19 akan meghentikan usaha hamper 24 juta orang di Asia Timur dan Pasifik. Bank dunia juga akan memperkirakan hamper 35 juta orang akan tetap dalam keadaan miskin, bahkan memperkirakan kemiskinan akan meningkat 922 juta diseluruh dunia. ${ }^{2}$ Selain hal tersebut di atas covid-19 memberikan dampak buruk bagi dunia kerja ini terlihat pada tingginya angka pemutusan hubungan kerja (PHK). Kementerian tenaga kerja menyebut sampai dengan Februari 2021 ada 29,12 juta penduduk Indonesia usia kerja terdampak covid-19 dengan kehilangan pekerjaannya. ${ }^{3}$

1 Zuraya Nadia, “Tiga Dampak Besar Pandemi Covid-19 Bagi Ekonomi RI,” pada Republika.com di akses pada 10 Maret 2020.

2 Azwar Iskandar dkk, Peran Ekonomi dan Keuangan Sosial Islam Saat Pandemi Covid19”, Vol.7 No.7 (Jurnal Sosial dan Budaya Syar'i: UIN Syarif Hidayatullah Jakarta, 2020), 626.

${ }^{3}$ Redaksi Warta Ekonomi Online, Pandemi bikin 29 juta Penduduk Usia Kerja di PHK, di akses pada https://www.wartaekonomi.co.id/read327242/pandemi-bikin-29-juta-penduduk-usia-kerja-di-phk pada 10 Maret 2021 pukul 20.00 WIB. 
Besarnya angka PHK akan berdampak pada menurunnya ekonomi keluarga. Jika hal tersebut tidak mampu diselesaikan dengan baik, maka akan berdampak pada tinggina tingkat criminal yang terjadi di masyarakat. secara sederhana, dapat dideskripsikan bahwa dampak yang terjadi akibat covid-19 mampu memberikan guncangan hebat terhadap melemahnya sector ekonomi secara keseluruhan. Sehingga membutuhkan solusi tersendiri untuk terus dapat bertahan hidup. Di antara bentuk upaya yang diserukan dan dilakukan oleh dunia dalam rangka mengurangi penyebaran wabah ini adalah dengan social atau physical distancing. Namun sayangnya, gerakan ini membawa pengaruh pada penurunan aktivitas ekonomi secara keseluruhan. ${ }^{4}$

Islam mengajarkan manusia untuk saling menyayangi, mengasihi dan menyantuni, memiliki konfigurasi kedermawanan atau filantropi dari ajarannya. ${ }^{5} \mathrm{Di}$ antaranya berupa perintah untuk berinfaq, bershodaqah, berzakat dan berwakaf yang dapat berfungsi untuk menumbuhkan rasa kemanusiaan yang tinggi, menghilangkan sifat kikir, rakus, materialistis, membersihkan jiwa dan memberikan ketenangan hidup juga mampu mengatasi masalah kehidupan social ekonomi, dan pendidikan. ${ }^{6}$ Peran ini diharapkan mampu mengatasi masalah ekonomi yang terjadi dan memberikan kontribusi solusi pemecahannya dimasyarakat khususnya umat muslim.

Keuangan social Islam sangatlah penting dan strategis karena banyak membantu masyarakat sehingga pengelola zakat dapat diibaratkan sebagai shelter kemanusiaan di tengah wabah Covid-19. Hal tersebut mendorong Menteri agama mengeluarkan surat edaran Nomor 8 Tahun 2020 tentang percepatan pembayaran dan Pendistribusian Zakat serta optimalisasi Wakaf sebagai jarring pengaman social dalam kondisi darurat kesehatan covid-19. ${ }^{7}$ MUI juga menetapkan fatwa ${ }^{8}$ yang di dalamnya berisi pendistribusian zakat produktif dalam bentuk tunai atau barang sebagai stimulus kegiatan social ekonomi fakir miskin, pemanfaatan harta zakat yang diwujudkan dalam bentuk asset kelolaan atau layanan bagi kebutuhan masyarakat umum misalnya kebutuhan pokok, APD, obat-obatan dan lain-lain.

\footnotetext{
${ }^{4}$ Ibid.

${ }^{5}$ Uyun Q, Zakat, Infak, Shodaqah dan Wakaf sebagai Konfigurasi Filantropi Islam”, Vol.2, No. 2, Jurnal Studi Islam: Islamuna, 2015), 218.

${ }^{6}$ Kasdi A, Filantropi Islam untuk Pemberdayaan Ekonomi Umat (Model Pemberdayaan Ziswaf di BMT Se Kabupaten Demak)Iqtishadia: Jurnal Kajian Ekonomi dan Bisnis Islam STAIN Kudus, Vol.9, No.2, 2016), 227.

7 Hafil Muhammad, "Pengelola Zakat Banyak Bantu Atasi Masalah Covid19, di akses pada Republika.co.id pada tanggal 10 Maret 2020 pukul 20.30 WIB.

8 Fatwa MUI Nomor 23 Tahun 2020 tentang pemanfaatan harta Zakat, Infak, Sedekah guna Penanggulangan Wabah covid-19 dan dampak yang ditimbulkannya.
} 
Berangkat dari kasus di atas bahwa covid-19 memberikan dampak yang begitu signifikan terhadap melemahnya sector ekonomi, maka zakat hadir sebagai filantropi yang mampu memberikan solusi atas krisis ekonomi yang terjadi dan keuangan social yang tidak stabil. Maka dari itu penting bagi kita untuk mengetahui kontribusi zakat atas krisis ekonomi yang terjadi dan keuangan social Islam di masa pandemic covid-19.

\section{TINJAUAN LITERATUR}

Studi tentang kontribusi zakat sebagai solusi menghadapi krisis ekonomi dan keuangan sosial Islam di masa pandemi covid-19 adalah penelitian baru. Beberapa penelitian yang membahas tentang kontribusi zakat di antaranya adalah karya Azwar Iskandar dkk, yang berjudul Peran ekonomi dan Keuangan Sosial Islam saat Pandemi Covid-19. Dari penelitian ini diperoleh hasil bahwa di antara solusi yang dapat ditawarkan dalam kerangka konsep dan sistem Ekonomi dan Keuangan Sosial Islam adalah: (1) dengan penyaluran bantuan langsung tunai yang berasal dari zakat, infak dan sedekah; (2) dengan penguatan wakaf baik berupa wakaf uang, wakaf produktif, waqf linked sukuk maupun wakaf untuk infrastruktur; (3) melalui bantuan modal usaha unggulan untuk sektor usaha atau Usaha Mikro Kecil Menengah (UMKM); (4) melalui skema qardhul hasan; (5) peningkatan literasi ekonomi dan keuangan syariah; (6) melalui pengembangan teknologi finansial syariah. ${ }^{9}$

Penelitian kedua adalah karya Jureid dengan judul Ekonomi Syariah sebagai alternatif Kesejahteraan Ekonomi Masyarakat Pada Era covid-19. Pada penetian ini diperoleh hasil bahwa ekonomi syariah dengan prinsip-prinsipnya berdasarkan Alquran dan Sunnah mampu menjadi solusi bagi kesejahteraan masyarakat, apalagi sekarang ini karena COVID-19. Dalam ilmu ekonomi Islam, terdapat nilai-nilai moral dan spiritual yang unggul yang menyatu. Dengan nilai-nilai dan sistem ekonomi syariah, masyarakat dapat sejahtera dan terhindar dari kekhawatiran akan kehidupan di masa depan akibat dampak COVID-19. Alternatif utama berbasis sistem ekonomi syariah dalam mensejahterakan masyarakat terdampak COVID-19 adalah zakat dan turunannya. Kajian ini menjadi bukti tak terbantahkan bahwa instrumen zakat memiliki potensi yang luar biasa. Untuk itu diperlukan komitmen dan kerjasama yang kuat antar seluruh pemangku kepentingan zakat, baik

${ }^{9}$ Azwar Iskandar dkk, "Peran Ekonomi dan Keuangan Sosial IslamSaat Pandemi Covid-19", Vol.7 No.7 Jurnal Sosial dan Budaya Syari: UIN Syarif Hidayatullah Jakarta, 2020. 
pemerintah, DPR, lembaga dan lembaga amil zakat, serta masyarakat secara keseluruhan dalam mewujudkan pembangunan zakat yang berkelanjutan. ${ }^{10}$

\section{METODE PENELITIAN}

Penelitian ini menggunakan metode penelitian deskriptif kualitatif sebagai upaya memahami konsep yang ditemukan dalam sebuah proses penelitian, dengan menggunakan teknik content analisis (analisis isi) dan riset kepustakaan (library research). Metode penelitian yang digunakan untuk mengetahui simpulan dari sebuah teks biasa disebut dengan teknik content analysis. Atau bisa diartikan dengan analisis isi merupakan metode penelitian yang dipergunakan untuk mengungkap gagasan peneliti yang termanifestasi maupun yang laten. Sedangkan library riset menggunakan jenis dan sumber data sekunderr yang diperoleh dari hasil penelitian yang dilakukan, artikel, buku, referensiyang membahasa topic yang berkaitan dengan temuan. ${ }^{11}$

Penelitian yang dijadikan rujukan selanjutnya adalah karya Umi Khusnul Khotimah dengan judul Filantropi Zakat: Solusi Stabilitas Ekonomi Syariah di tengah Pandemi Covid19. Hasil penelitian ini adalah Syariat zakat mempunyai dua dimensi, yaitu ketaatan dan kepedulian sosial. Di tengah wabah corona yang melanda umat manusia, zakat dapat menjadi solusi sebagai stabilisasi ekonomi. Karena dengan distribusi zakat sesuai sasaran tanpa tebang pilih, maka masyarakat miskin tetap mampu membeli kebutuhan sehari-hari. Sehingga putaran ekonomi tidak akan terhenti. Agar dayaguna zakat meningkat, harus diperhatikan kebutuhan mendasar mustahik zakat. Sebagai solusi zakat bisa diberikan dalam bentuk tunai supaya kesulitan ekonomi mereka dapat teratasi. Implentasinya akan lebih mudah jika pembayaran zakat dilaksanakan dengan harga. ${ }^{12}$

Dari penjabaran ketiga kajian terdahulu di atas, yang membedakan penelitian adalah mengungkap sejauh mana peran zakat dalam mengahadapi krisis ekonomi dan keuangan sosial dalam masa pandemi covid-19.

${ }^{10}$ Jureid, "Ekonomi Syariah Sebagai Alternatif Kesejahteraan Ekonomi Masyarakat Pada Era Covid19”, Vol.5, No.2 Jurnal Kajian Ekonomi dan Kebijakan Publik, 2020.

${ }^{11}$ Azwar Iskandar dan Khaerul Aqbar, "Kedudukan Ilmu Ekonomi Islam di antara Ilmu ekonomi dan Fikih Muamalah: Analisis Problematika Epistemologi’, Nukhbatul 'ulum: Jurnal Bidang Kajian Islam: Vol.5, No. 2, 2019), 88 .

${ }^{12}$ Umi Khusnul Khotimah dengan judul Filantropi Zakat: Solusi Stabilitas Ekonomi Syariah di tengah Pandemi Covid-19. Vol.4, No.2 Jurnal Al Mizan, 2020. 


\section{HASIL DAN PEMBAHASAN}

\section{A. Pengertian dan Tujuan zakat}

Zakat berasal dari bahasa arab zaka yang berarti berkah, tumbuh, berkembang, bertambah, bersih, baik, suci dan terpuji. ${ }^{13}$ sedangkan menurut Istilah zakat merupakan sejumlah harta tertentu yang diwajibkan oleh Allah kepada orang yang berhak menerima setelah mencapai nisab dan haul. Secara urf, zakat adalah bagian tertentu dari harta yang telah ditetapkan Allah sebagai hak orang fakir. ${ }^{14}$

Menurut Madzhab Maliki zakat adalah mengeluarkan sebagian dari harta tertentu yang telah mencapai nisab kepada orang yang berhak jika kepemilikan genap selama satu tahun, selain barang tambang, tanaman dan harta temuan. Hanafiyah lebih menekankan pada kepemilikan, yaitu pemberian hak kepemilikan atas sebagian harta tertentu dari harta tertentu kepda orang lain yang telah ditetapkan oleh syariat semata-mata karena Allah. ${ }^{15}$ Menurut Syafi'iyah zakat adalah nama yang disebutkan untuk barang yang dikeluarkan dari harta ata badan manusia kepada pihak tertentu. Sedangkan Hanabilah mengartikan zakat sebagai hak yang wajib pada harta tertentu kepada kelompok tertentu dan waktu tertentu. ${ }^{16}$

Zakat menurut pengertian Undang-undang adalah harta yang wajib dikeluarkan oleh seseorang muslim atau badan usaha untuk diberikan kepada yang memiliki hak menerimanya sesuai dengan syariat Islam. ${ }^{17}$ Adapun tujuan disyariatkannya zakat adalah: $^{18}$

1. Mengurangi kesenjangan social dimasyarakat

2. Membentu orang-orang fakir dan miskin yang membutuhkan bantuan financial

3. Mampu menjadi sarana pengentasan kemiskinan

4. Meningkatkan taraf hidup mustahik

5. Membersihkan muzakki dari karakter-karakter negative yang disematkan Allah ke dalam Al-Qur'an kepada manusia, seperti kikir dan rakus.

6. Mengobati hati dari cinta dunia

7. Melatih diri untuk meneladani sifat Rasulullah

${ }^{13}$ Umi Khusnul Khotimah, "Filantropi Zakat: Solusi Stabilitas Ekonomi Syariah di Tengah Pandemi Covid-19”, Jurnal al-Mizan, Vol.4, No. 2, 2020), 38.

${ }^{14}$ Wahbah Az-Zuhaily, Fiqih Islam Wa Adillatuhu Juz III (Bierut: Dzar al Fikr, 2007), 1788.

${ }^{15}$ Ibid.

${ }^{16}$ Ibid.

${ }^{17}$ Undang-Undang Pengelolaan Zakat No.23 Tahun 2011

${ }^{18}$ Ali Ahmad Al-Jurjawi, Hikmah AlTasyri' wa falsafatuhu, jiid 1, 167. 
8. Menjaga harta agar terhindar dari orang yang punya penyyakit hati

9. Sebagai wujud rasa syukur kepada Allah atas nikmat berupa harta.

\section{B. Regulasi Zakat di Indonesia}

Pengelolaan zakat di Indonesia mengalami peningkatan yang terjadi dari waktu ke waktu meskipun belum terealisasi secara sempurna. Pada zaman dahulu, pengumpulan zakat dilakukan dengan sukarela atas kesadaran individu muslim sebagai aplikasi dari agama yang dianut yang karena mengaharap Ridha Allah semata. Pada tahun 1858 pemerintah colonial belanda membuat peraturan kebijakan bahwa praktik zakat dilakukan secara netral dan tidak ada campur tangan dari pemerintah belanda. Sehingga dana zakat dapat dimanfaatkan untuk kepentingan pendidikan dan kegiatan social, sehingga hal tersebut menjadikan pengumpulan zakat terbagi menjadi dua, pertama pengumpulan aktif yang dilakukan oleh hakim yang bersifat wajib, dan kedua adalah pengumpulan pasif yang dilakukan pemuka agama dan bersifat sukarela. Rintisan pengelolaan zakat secara modern dilakukan oleh ormas muhammadiyah dengan alas an, teologi al-Maun modernism dan etos puritan. ${ }^{19}$

Setelah Indonesia memperoleh kemerdekaan dan dibentuklah Departemen Agama maka mucullah surat edaran yang menyatakan bahwa Departemen Agama tidak akan ikut campur dalam pengelolaan zakat, pemerintah hanya memberikan fasilitas kehidupan beragama saja. Seiring berjalannya waktu, pada tahun 1968 terbitlah Peraturan Menteri Agama tentang Pendirian Baitul Maal diseluruh daerah yang bertanggung jawab terhadap pengelolaan zakat. Setelah itu, lalu muncullah berbagai Lembaga amil zakat dan Badan Amil zakat. Sampai saat ini ada 8 regulasi yang mengatur pengelolaan zakat di Indonesia, yaitu:

1. UU Nomor 23 Tahun 2011 tentang Pengelolaan Zakat;

2. PP 14 Tahun 2014 tentang Pelaksanaan UU Nomor 23 Tahun 2011;

3. PMA Nomor 52 Tahun 2014 tentang Syarat dan Tata Cara Penghitungan Zakat Mal Dan Zakat Fitrah serta Pendauagunaannya untuk Usaha Produktif;

4. PMA Nomor 69 tentang Perubahan atas PMA 52 Tahun 2014;

5. PMA Nomor 5 Tahun 2016 tentang Tata Cara Pengenaan Sanksi Administrasi dalam pengelolaan Zakat.

19 Lukmanul Hakim, Regulasi Zakat di Indonesia, kebijakan Setengah hati. Diakses pada https://www.kompasiana.com/lukman45/569e66af177b61fc0c4e5c59/regulasi-zakat-di-indonesia-kebijakansetengah-hati?page=all, pada tanggal 12 Maret 2021 Pukul 14.00 WIB. 
6. SK Dewan Pertimbangan BAZNAS Nomor 001/DP- BAZNAS/XII/2010 tentang Pedoman Pengumpulan dan Pentasharrufan ZIS pada Badan Amil Zakat Nasional;

7. Keputusan Ketua BAZNAS Nomor Kep.016/BP/BAZNAS/XII, tentang Nilai Nishab Zakat Pendapatan atau Profesi tahun 2016;

8. Keputusan Ketua BAZNAS Nomor 142 Tahun 2017 tentang Nilai Nishab Zakat Pendapatan Tahun 2017. ${ }^{20}$

\section{Krisis ekonomi dan Keuangan Sosial Islam}

Krisis ekonomi adalah salah satu hal yang paling ditakuti oleh negara di seluruh dunia. Bagaimana tidak, jika hal tersebut terjadi, kerugian akan menimpa pemerintah dan masyarakat sekaligus. Akhir-akhir ini, masyarakat sedang marak-maraknya memperbincangkan keadaan ekonomi di Indonesia karena adanya pandemi virus corona.

Menurut Market Business News, krisis ekonomi adalah keadaan di mana perekonomian di suatu negara mengalami penurunan secara drastis. Secara umum, negara yang menghadapi keadaan tersebut akan mengalami penurunan PDB (produk domestik bruto), anjloknya harga properti dan saham, serta naik turunnya harga karena inflasi. Gejala yang muncul saat krisis ekonomi biasanya diawali oleh penurunan belanja dari pemerintah. Lalu, jumlah pengangguran melebihi $50 \%$ dari jumlah tenaga kerja. Selain itu, terjadi pula kenaikan harga pokok yang semakin meroket, penurunan konsumsi yang rendah, penurunan nilai tukar yang tidak terkontrol, dan penurunan pertumbuhan ekonomi yang drastis. ${ }^{21}$

Adapun penyebab terjadinya krisis adalah:

1. Hutang yang berlebihan; penyebab trjadinya krisis ekonomi adalah hutag Negara yang berlebih sehingga tidak mampu membayarnya

2. Laju Inflasi yang tinggi; inflasi terjadi karena harga barang dan jasa mengalami kenaikan dalam jangka waktu yang panjang. sehingga mengakibatkan nilai uang turun dan membuat perekonomina menurun.

\footnotetext{
${ }^{20}$ Umi Khusnul, Khotimah, Filantropi Zakat......44.

21 Maulana Adib, Ditakuti oleh Semua Negara: Apa Penyebab Krisis Ekonomi? Diakses pada https://glints.com/id/lowongan/krisis-ekonomi/\#.YExNhG8zbMw pada tanggal 11 Maret 2020 pukul 20.00 WIB
} 
3. Pertumbuhan ekonomi yang macet; semakin buruk pertumbuhan ekonomi maka ada kemungkinan Negara tersebut mengalami penurunan pertumbuhan ekonomi atau krisis ekonomi. ${ }^{22}$

Dampak terjadinya krisis ekonomi yaitu Krisis ekonomi memberikan dampak yang sangat besar bagi negara dan tentunya dari berbagai pihak, mulai dari pemerintah hingga masyarakat. ketika suatu negara mengalami peristiwa tersebut, dipastikan banyak perusahaan yang melakukan pemutusan hubungan kerja (PHK) kepada karyawannya. Hal tersebut dilakukan karena perusahaan tidak memiliki cukup uang untuk memberikan gaji kepada mereka.

Dengan kejadian tersebut, dipastikan juga angka pengangguran akan semakin naik. Setelahnya, angka kemiskinan juga meningkat karena orang-orang tidak memiliki pendapatan. Selain itu, pemerintah dipastikan akan kesulitan dalam memenuhi kebutuhan belanja Negara dan masyarakat juga kesulitan memenuhi kehidupan sehari-hari karena harga kebutuhan naik secara tajam.

Ada beberapa keuangan social Islam di antaranya adalah zakat, infak, Shodaqah dan Wakaf. Dana ziswa di nilai mampu mengurangi kemiskinan karena lembaga keuangan Islam dapat menjalankan berbagai aktivitas produktif baik secara langsung maupun tidak langsung dengan sikap kebijakan yang lentur, terstruktur dan terukur. Keuangan Sosial Islam juga memainkan perannya sebagai salah satu agent of asset yang mampu memberdayakan ekonomi umat khususnya perempuan. ${ }^{23}$

Dalam kegiatan bisnis keuangan social Islam dapat memberikan kontribusi dan perannya kepada masyarakat yang membutuhkan dukungan modal dan melayani masyarakat yang Ingin menitipkan dananya kepada lembaga keuangan Islam dengan konsp syriah dalam situasi covid-19.

\footnotetext{
22 Ibid.

${ }^{23}$ https://glints.com/id/lowongan/krisis-ekonomi/\#.YExNhG8zbMw
} 


\section{Zakat Sebagai solusi menghadapi Krisis ekonomi dan Keuangan Sosial Islam di Masa Pandemi Covid19}

Zakat adalah sejumlah harta tertentu yang diwajibkan Allah diserahkan kepada orangorang yang berhak. Zakat juga bisa berati mengeluarkan jumlah tertentu itu sendiri. Secara lebih luas pengertian zakat adalah harta yang wajib dikeluarkan oleh seorang muslim atau badan usaha untuk diberikan kepada yang berhak menerimanya sesuai dengan syariat Islam. Syariat zakat mempunyai dua dimensi, yaitu ketaatan dan kepedulian sosial. Di tengah wabah corona yang melanda umat manusia, zakat dapat menjadi solusi sebagai stabilisasi ekonomi memperbaiki krisis dan keuangan sosial. Karena dengan distribusi zakat sesuai sasaran tanpa membeda-bedakan, maka masyarakat miskin tetap mampu memenuhi kebutuhan sehari-hari. Sehingga perputaran ekonomi dapat terus berjalan.

Pada situasi pandemi seperti sekarang ini diperlukan edukasi edukasi dan sosialisai tentang percepatan pembayaran zakat agar lebih mampu memberikan manfaat. Meningkatnya angka kemiskinan akibat wabah, maka akan berdampak pada meningkatnya masyarakat yang memerlukan dana zakat.

Di antara solusi yang dapat ditawarkan dalam mengahadapi krisis Ekonomi dan Keuangan Sosial Islam adalah:

Pertama, penyaluran bantuan langsung tunai yang berasal dari zakat, infak dan sedekah, baik yang berasal dari unit-unit pengumpul zakat maupun dari masyarakat. Menghadapi situasi seperti sekarang ini, bukan hanya pemerintah yang bergerak, masyarakat pun diharapkan mampu memberikan berkontribusi sesuai dengan kemampuan dan kondisinya masing-masing. Dalam konteks ini, diperlukan pengorbanan dari orang kaya dan kesabaran dari orang miskin yang terdampak wabah, atas dasar cinta yang diwujudkan dalam bentuk solidaritas sesama manusia, di mana orang yang lebih beruntung membantu mereka yang kurang beruntung. ${ }^{24}$ Salah satu wujudnya adalah menunaikan zakat yang disalurkan langsung kepada mustahik.

Hal ini adalah skema philanthropy Ekonomi Islam yang memiliki potensi besar bagi perekonomian masyarakat. Namun sayangnya, realisasi zakat yang masuk ke Baznas

${ }^{24}$ Linge, A., Filantropi Islam Sebagai Instrumen Keadilan Ekonomi (Jurnal Perspektif Ekonomi Darussalam, Vol . 1, No. 2, 2015), 154-171. 
masih jauh dari harapan. Realisasi zakat di akhir tahun 2018 tercatat hanya $R p$ 8,1 triliun, padahal potensinya mencapai Rp 252 triliun. Untuk itu, penguatan kampanye dana zakat, infak, dan sedekah dapat terus digiatkan. Diantara upaya yang dapat dilakukan adalah:

1. Menjadikan masjid sebagai pusat baitul maal untuk masyarakat sekitarnya dan wajib didaftar sebagai Unit Pengumpul Zakat (UPZ) di bawah koordinasi Organisasi Pengelola Zakat (OPZ). Meski masjid-masjid saat ini sementara tidak difungsikan, di era media sosial ini jamaah masjid tetap dapat digerakkan dengan membayar zakat secara online;

2. Literasi terkait perhitungan zakat dapat dikuatkan dengan pendirian Zakat Centre di masjid dan kampus-kampus;

3. Perlu menyerukan gerakan Solidarity Fund secara nasional dan besar-besaran yang dapat dipimpin langsung oleh Presiden Republik Indonesia yang didukung oleh seluruh media mainstream nasional atau media sosial resmi pemerintah dan masyarakat. Jika zakat melibatkan dua pihak, yaitu pemerintah atau yang mewakilinya, dalam hal ini amil zakat (Baznas), dan wajib zakat (muzakki), maka infak dan sedekah sifatnya lebih fleksibel, karena hanya berasal dari satu pihak saja yaitu pembayar/pemberi infak atau sedekah, sehingga pengumpulan dan penyaluran dapat dilakukan lebih maksimal untuk masyarakat terdampak Covid-19.

Kedua, bantuan modal usaha unggulan saat krisis. Di tengah-tengah krisis, tidak sedikit sektor usaha atau Usaha Mikro Kecil Menengah (UMKM) yang berjuang agar tetap eksis. Usaha ini seringkali sulit bertahan karena keterbatasan permodalan. Keberadaan UMKM sebagai kelompok non-muzakki adalah kelompok yang sangat rentan untuk jatuh ke dalam jurang kemiskinan dan kebangkrutan karena guncangan atau hantaman shock ekonomi. Sehingga jumlah mustahik dapat meningkat dengan sangat tajam, sementara jumlah muzakki dapat terus menurn secara signifikan. ${ }^{25}$

Keberadaan pengusaha mikro kecil dan menengah, khususnya pedagang di pasar tradisional merupakan wujud kehidupan ekonomi sebagian besar rakyat Indonesia. Posisi ini telah menempatkan pedagang pasar tradisional sebagai hal utama yang harus

${ }^{25}$ Ascarya, The Role of Islamic Social Finance in Times of Covid-19 Outbreak, PEBS-UI (April 2020): 25. 
mendapat perhatian, terutama dalam hal permodalan. Proses pengembangan pedagang pasar tradisional adalah manifestasi dari perkembangan ekonomi yang menjadi sangat penting. Upaya pengembangan dan penguatan potensi pedagang pasar tradisional sebagai kelompok ekonomi strategis harus berorientasi pada pemberdayaan, sehingga terbentuk pelaku ekonomi lokal yang mandiri dan kuat melalui Lembaga Keuangan Mikro (LKM) khususnya Lembaga Keuangan Mikro Syariah (LKMS). ${ }^{26}$ Oleh karena itu, pemberian modal pada usaha dijadikan sebagai sarana mengurangi dampak krisis. Pemberian modal ini dapat dilakukan dengan beberapa alternatif kebijakan, seperti pemberian stimulasi tambahan relaksasi perbankan syariah dan restrukturisasi atau penangguhan pembayaran kredit/pembiayaan syariah selama beberapa bulan ke depan. Agar lebih kuat, pemberian permodalan dari perbankan/lembaga keuangan syariah ini perlu didukung dan dikuatkan dengan pendampingan sehingga dapat dipertanggungjawabkan.

Ketiga, permodalan usaha di atas juga dapat diikuti dengan pinjaman qardhul hasan. Dalam terminologi ekonomi/keuangan syariah, qardhul hasan adalah pinjaman yang tidak mengambil manfaat (keuntungan) apa pun namun tetap ditekankan untuk dibayarkan kembali. Produk/skema ini merupakan salah satu produk/skema sistem keuangan syariah yang sangat penting dalam mendukung pemulihan atau menopang perekonomian. Diantara pilihan penyaluran yang dapat dilakukan adalah melalui:

1. Lembaga Keuangan Mikro Syariah (LKMS) dalam membiayai usaha nano dimana dananya dapat berasal dari beberapa sumber, baik dari masyarakat umum, perusahaan swasta maupun BUMN/BUMD;

2. Pinjaman langsung tanpa margin baik untuk usaha maupun konsumsi yang disalurkan oleh perusahaan (swasta atau BUMN/BUMD) kepada karyawan atau mitranya (seperti pengemudi ojek online) dimana dananya dapat berasal dari dana Corporate Social Responsibility (CSR) atau pos lainnya. Untuk meningkatkan dana CSR, pemerintah perlu mempertegas kewajiban dan kontribusi CSR yang lebih tinggi baik dari BUMN/BUMD maupun perusahaan swasta. Dalam pandangan Islam, aktivitas bisnis adalah bagian dari kewajiban keagamaan.

26 Sabirin, S., \& Sukimin, D. A., Islamic Micro Finance Melati: Sebuah Upaya Penguatan Permodalanbagi Pedagang Pasar Tradisional (Economica: Jurnal Ekonomi Islam, Vo. 8, No. 1, 2017), $27-53$. 
Social reponsibility (pertanggungjawaban sosial) mengacupada kewajibankewajiban di mana organisasi harus melindungi dan berkontribusi pada masyarakat dimana organisasi itu berada. Di dalam Islam dikenal konsep persaudaraan dan keadilan sosial, yang bisa dilakukan dengan cara berbagi keuntungan/kemakmuran dengan masyarakat di sekitarnya. Dengan cara seperti itu, perusahaan tersebut telah menunaikan tanggung jawab sosial perusahaannya. $^{27}$

3. Baitul Mal wa Tamwil (BMT), melalui Baitul Mal-nya menjadi salah satu lembaga yang dapat berperan serta dalam memberikan solusi terhadap masalah ini, yaitu dengan cara melaksanakan program-program pemberdayaan melalui produk qardhul hasan. 23 Implementasi qardhul hasan ini tidak hanya berfungsi sebagai wadah pembiayaan semata, akan tetapi bentuk pembiayaan ini juga dibekali dengan model pendampingan, sehingga dengan adanya pendampingan ini pelaksanaan model pembiayaan dapat berjalan dengan baik dan pada akhirnya tujuan mulia ini juga akan terwujud.

Keempat, selain dari sektor perbankan syariah dan qardhul hasan, sebagian dana yang dikumpulkan oleh unit-unit atau organisasi pengumpul zakat, khususnya yang ada di daerah, dapat digunakan untuk memperkuat usaha UMKM. Menyelamatkan kelompok UMKM yang krisis atau terancam bangkrut karena terkena dampak ekonomi dari wabah Covid-19, dapat dikategorikan sebagai golongan asnaf (penerima zakat), yaitu sebagai kelompok miskin, berjuang di jalan Allah (fii sabilillah), atau orangyang berhutang (gharimin).

Kelima, Sistem Ekonomi dan Keuangan Syariah sebagai sistem yang sarat dengan nilai sekaligus merupakan petunjuk dari Sang Pencipta diyakini mampu mewujudkan kegiatan ekonomi yang produktif dalam kerangka keadilan. Untuk itu, masyarakat perlu diberi pemahaman yang benar tentang ekonomi dan keuangan syariah dalam rangka peningkatan literasi ekonomi dan keuangan syariah, diantaranya melalui pengadaan bantuan pendidikan ekonomi syariah untuk

\footnotetext{
${ }^{27}$ Satrio, M. A., Qardhul Hasan Sebagai Wujud Pelaksanaan CSR dan Kegiatan Filantropi Lembaga Keuangan Syariah Untuk Pemberdayaan Masyarakat (Kajian Bisnis Sekolah Tinggi Ilmu Ekonomi Widya Wiwaha, Vol. 23, No. 2, 2015), 104-111.
} 
mahasiswa terkena dampak Covid-19; pemberian perizinan dan fasilitas bagi Perguruan Tinggi Negeri dan Swasta untuk menjalankan program Program Jarak Jauh (PJJ) yang menawarkan program Ekonomi Syariah dengan salah satu penekanan pada pembinaan akhlak; dan perluasan infrastruktur sambungan internet penunjang PJJ yang merata di seluruh Indonesia secara gratis. Selain itu, keberadaan Organisasi Masyarakat Ekonomi Syariah sebagai wadah yang bertujuan menjadi acuan dan diikuti sebagai teladan bagi usaha percepatan pengembangan dan penerapan sistem ekonomi serta etika bisnis islami di Indonesia dapat dilibatkan dalam upaya ini. Literasi Keuangan Syariah di Indonesia masih kategori rendah. ${ }^{28}$.

Keenam, pengembangan teknologi finansial syariah untuk memperlancar likuiditas pelaku pasar daring secara syariah, di mana pada saat yang bersamaan juga diupayakan peningkatan fokus pada social finance (zakat, infak, sedekah dan wakaf) di samping commercial finance. Termasuk pula dalam hal ini, pengembangan market place untuk mengumpulkan pasar tradisional dan UMKM yang berjumlah hampir 60 juta saat ini, dengan tujuan mempertemukan permintaan dan penawaran baik di dalam negeri maupun luar negeri, khususnya di masa-masa lockdown karena pandemi. Apalagi penelitian yang ada menyebutkan bahwa permasalahan keuangan, sumberdaya manusia, dan teknologi merupakan permasalahan klasik. ${ }^{29}$ Yang dihadapi Usaha Mikro, Kecil, dan Menengah (UMKM) di Indonesia. Perkembangan teknologi di bidang keuangan telah berkembang dalam beberapa tahun terakhir ini dan berdampakperubahan perilaku masyarakat dalam bertransaksi keuangan. Hal ini dapat menjadi solusi bagi permasalahan keuangan yang dihadapi UMKM. ${ }^{30}$

28 Hayati, S. R., Strategi Bank Syariah dalam Meningkatkan Literasi Keuangan Syariah pada Masyarakat (Studi Kasus pada BPRS Madina Mandiri Sejahtera) (JESI (Jurnal Ekonomi Syariah Indonesia), Vol. 8, No. 2,2019), 129-137.

29 Hiyanti, H., Nugroho, L., Sukmadilaga, C., \& Fitrijanti, T. Peluang dan Tantangan Fintech (Financial Technology) Syariah di Indonesia (Jurnal Ilmiah Ekonomi Islam, 5(3), 2020), 326-333.

${ }^{30}$ Yuliana, R. R. R. D. (2019). Sinergi lembaga teknologi finansial dan koperasi dalam pemanfaatan teknologi finansial oleh usaha mikro, kecil, dan menengah di NTB. (Jurnal Ekonomi dan Pembangunan, 27(1), 2019), 53-66. 


\section{KESIMPULAN}

Dari paparan di atas dapat disimpulkan bahwa zakat memiliki dimensi ketaatan dan kepedulian social. Di antara bentuk ketaatan adalah adanya perintah untuk melakukan pembayaran zakat dan sebagai wujud dari kepedulian social adalah zakat didistribusikan kepada mustahik. Terlebih dimasa pandemic seperti ini, banyak orang yang membutuhkan bantuan karena terhimpit keadaan di ambang kemiskinan.

Adapun kontribusi yang diberikan zakat untuk menjadi solusi krisis dimasa pandemic adalah pertama, merealisasikan zakat untuk didistribusi sebagai bentuk bantuan langsung dan manfaatnya bisa dirasakan secara langsung, kedua, zakat dapat digunakan sebagai bantuan modal usaha dalam bentuk Qardul Hasan tanpa adanya tambahan margin. ketiga, dana yang terkumpul di BAZ/LAZ/organisasi pengumpul zakat dapat digunakan untuk memperkuat UMKM. Keempat, zakat dapat ditingkatkan dengan penggunaan fintech syariah.

\section{REFERENSI}

Adib, Maulana . Ditakuti oleh Semua Negara: Apa Penyebab Krisis Ekonomi? Diakses pada https://glints.com/id/lowongan/krisis-ekonomi/\#.YExNhG8zbMw pada tanggal 11 Maret 2020 pukul 20.00 WIB

Ahmad Al-Jurjawi, Ali .Hikmah AlTasyri’ wa falsafatuhu, jiid 1.

Ascarya, The Role of Islamic Social Finance in Times of Covid-19 Outbreak, PEBS-UII. April 2020.

Az-Zuhaily, Wahbah. Fiqih Islam Wa Adillatuhu Juz III. Bierut: Dzar al Fikr, 2007.

Fatwa MUI Nomor 23 Tahun 2020 tentang pemanfaatan harta Zakat, Infak, Sedekah guna Penanggulangan Wabah covid-19 dan dampak yang ditimbulkannya.

H., Hiyanti, Nugroho, L., Sukmadilaga, C., \& Fitrijanti, T. Peluang dan Tantangan Fintech (Financial Technology) Syariah di Indonesia (Jurnal Ilmiah Ekonomi Islam, 5(3), 2020 .

Hakim, Lukmanul . Regulasi Zakat di Indonesia, kebijakan Setengah hati. Diakses pada https://www.kompasiana.com/lukman45/569e66af177b61fc0c4e5c59/regulasi-zakat-diindonesia-kebijakan-setengah-hati?page=all, pada tanggal 12 Maret 2021 Pukul 14.00 WIB.

Hayati, S. R., Strategi Bank Syariah dalam Meningkatkan Literasi Keuangan Syariah pada Masyarakat (Studi Kasus pada BPRS Madina Mandiri Sejahtera) (JESI : Jurnal Ekonomi Syariah Indonesia), Vol. 8, No. 2,2019.

https://glints.com/id/lowongan/krisis-ekonomi/\#.YExNhG8zbMw 
Iskandar, Azwar dan Khaerul Aqbar, "Kedudukan Ilmu Ekonomi Islam di antara Ilmu ekonomi dan Fikih Muamalah: Analisis Problematika Epistemologi', Nukhbatul 'ulum: Jurnal Bidang Kajian Islam: Vol.5, No. 2, 2019.

Iskandar, Azwar dkk, Peran Ekonomi dan Keuangan Sosial Islam Saat Pandemi Covid19”, Vol.7 No.7, Jurnal Sosial dan Budaya Syar'i: UIN Syarif Hidayatullah Jakarta, 2020.

Jureid, " Ekonomi Syariah Sebagai Alternatif Kesejahteraan Ekonomi Masyarakat Pada Era Covid-19”, Vol.5, No.2 Jurnal Kajian Ekonomi dan Kebijakan Publik, 2020.

Kasdi A, Filantropi Islam untuk Pemberdayaan Ekonomi Umat (Model Pemberdayaan Ziswaf di BMT Se Kabupaten Demak)Iqtishadia: Jurnal Kajian Ekonomi dan Bisnis Islam STAIN Kudus, Vol.9, No.2, 2016.

Khusnul Khotimah, Umi. "Filantropi Zakat: Solusi Stabilitas Ekonomi Syariah di tengah Pandemi Covid-19. Vol.4, No.2 Jurnal Al Mizan, 2020.

Linge, A., Filantropi Islam Sebagai Instrumen Keadilan Ekonomi (Jurnal Perspektif EkonomiDarussalam, Vol . 1, No. 2, 2015.

Muhammad, Hafil. "Pengelola Zakat Banyak Bantu Atasi Masalah Covid19, di akses pada Republika.co.id pada tanggal 10 Maret 2020 pukul 20.30 WIB.

Nadia, Zuraya. "Tiga Dampak Besar Pandemi Covid-19 Bagi Ekonomi RI," pada Republika.com di akses pada 10 Maret 2020.

Redaksi Warta Ekonomi Online, Pandemi bikin 29 juta Penduduk Usia Kerja di PHK, di akses pada https://www.wartaekonomi.co.id/read327242/pandemi-bikin-29-jutapenduduk-usia-kerja-di-phk pada 10 Maret 2021 pukul 20.00 WIB.

S., Sabirin \& Sukimin, D. A., "Islamic Micro Finance Melati: Sebuah Upaya Penguatan Permodalan bagi Pedagang Pasar Tradisional ." Economica: Jurnal Ekonomi Islam, Vo. 8, No. 1, 2017.

Satrio, M. A., Qardhul Hasan Sebagai Wujud Pelaksanaan CSR dan Kegiatan Filantropi Lembaga Keuangan Syariah Untuk Pemberdayaan Masyarakat (Kajian Bisnis Sekolah Tinggi Ilmu Ekonomi Widya Wiwaha, Vol. 23, No. 2, 2015.

Undang-Undang Pengelolaan Zakat No.23 Tahun 2011

Uyun, Q. "Zakat, Infak, Shodaqah dan Wakaf sebagai Konfigurasi Filantropi Islam”, Vol.2, No. 2, Jurnal Studi Islam: Islamuna, 2015.

Yuliana, R. R. R. D. (2019). Sinergi lembaga teknologi finansial dan koperasi dalam pemanfaatan teknologi finansial oleh usaha mikro, kecil, dan menengah di NTB. (Jurnal Ekonomi dan Pembangunan, 27(1), 2019. 